\title{
Compare the safety and efficacy of intravenous iron supplementation with iron sucrose to the oral supplementation with ferrous ascorbate in subjects with post-partum anemia
}

\author{
Ganesh Mhaske1, Preeti Vadehra ${ }^{1 *}$, Chandrakala Maran ${ }^{2}$
}

\begin{abstract}
${ }^{1}$ Department of Obstetrics and Gynecology, Smt. Kashibai Navale Medical College and General Hospital, Maharashtra, India

${ }^{2}$ Department of Obstetrics and Gynecology K. G. Hospital and Super Specialty Hospital, Coimbatore, Tamil Nadu, India
\end{abstract}

Received: 02 June 2019

Revised: 20 July 2019

Accepted: 08 August 2019

\section{*Correspondence: \\ Dr. Preeti Vadehra, \\ E-mail: drpreeti20@yahoo.com}

Copyright: (c) the author(s), publisher and licensee Medip Academy. This is an open-access article distributed under the terms of the Creative Commons Attribution Non-Commercial License, which permits unrestricted non-commercial use, distribution, and reproduction in any medium, provided the original work is properly cited.

\begin{abstract}
Background: The post-partum period is challenging enough for most new mothers. Recovering from birth, learning to parent, and taking care of her child requires lot of energy. Having anemia in postpartum period can make this process much more difficult. According to WHO, in India incidence of anemia in postnatal mother is around 58\% and according to ICMR prevalence of anemia in Tamil Nadu population $76 \%$ during pregnancy. The objective of this study was to compare the efficacy of intravenous iron supplementation with Iron sucrose to the oral supplementation with ferrous ascorbate in management of patient with post-partum anemia. To study the safety and side effects of these two preparations.

Methods: This was a prospective study conducted on 100 post-partum anemic women in KG Hospital in Coimbatore, October 2012 to November 2013 with hemoglobin less than $10 \mathrm{~g} / \mathrm{dl}$ but more than $6 \mathrm{~g} / \mathrm{dl}$ within 24-48 hours of delivery ,after satisfying inclusion and exclusion criteria were included in the study.

Results: Mean hemoglobin of oral group was $8.49 \pm 0.75$ and mean hemoglobin of IV group was $8.43 \pm 0.76 ; 24$ hours after delivery. After treatment, that is after 4 weeks mean hemoglobin of oral group was $10.38 \pm 0.79$ and mean hemoglobin of IV group was 11.20 \pm 0.71 .on comparing both groups, the increase in hemoglobin in the IV groups was significant. Reticulocyte count and other parameters increased significantly after four wks of starting therapy in IV group compare to the oral group. No major side effects or anaphylactic reactions were noted during study period.

Conclusions: Intravenous iron sucrose complex is safe, convenient and effective in postpartum anemic women as compared with the oral ferrous ascorbate. Intravenous iron sucrose have shorter treatment periods, increased likelihood of compliance, a lack of gastrointestinal side effects, and rapid replenishment of iron stores, making them superior to oral ferrous ascorbate.
\end{abstract}

Keywords: Ferrous ascorbate, Iron sucrose, Oral iron therapy, Postpartum iron deficiency anaemia, Parentral iron therapy

\section{INTRODUCTION}

The post-partum period is challenging enough for most new mothers. Recovering from birth, learning to be parent, and taking care of her child requires lot of energy.
Having anemia in postpartum period can make this process much more difficult.

Haemoglobin is an oxygen carrying constituent built in red blood cells. Since red blood cells are responsible for 
delivering oxygen to other cells in the body, any problem with oxygen delivering system which occurs in anemia, results in impaired physical work capacity, fatigue, depression, cognitive dysfunction, stress, and anxiety. ${ }^{1}$

It can also interrupt mother-child bonding. Studies have shown that infants of anemic mothers had delayed development, possibly reason due to the anemic mothers were significantly more "negative" towards their baby, and were less "responsive" than non-anemic mothers. ${ }^{2}$

According to the National pregnancy nutrition surveillance system, $29.8 \%$ of women who were not previously anemic during pregnancy become anemic after delivery. ${ }^{3}$ The physiological effects of pregnancy and blood loss at birth can exacerbate anemia. Anemia is a common complication for lactating mothers, partly as a result of the high incidence of anemia in pregnancy. ${ }^{4} \mathrm{~A}$ study from South Africa showed that iron status was associated with depression, stress and cognitive functioning in poor African mothers during the postpartum period. ${ }^{5}$ Another study results suggest that anemia is associated with the development of insufficient milk, which in turn is related to duration of full breastfeeding and age at weaning of the baby. Iron deficiency anemia lowers maternal immune response which predisposes the breastfeeding mother to clogged milk ducts, mastitis, thrush, prolonged tissue repair for sore nipple management as well as adversely affecting milk quality and breast milk volume. ${ }^{6}$

The standard approach to treatment in majority of institutions is oral supplementation with blood transfusion reserved for more severe or symptomatic cases. ${ }^{7}$ There are number of hazards of blood transfusion including transfusion of wrong blood, anaphylaxis and risk of transmission of infections, any of which would devastating for young mother. ${ }^{8}$

Long-term oral treatment can produce side effects and associated with increased oxidative damage which can lead to non-compliance and difficulty in monitoring. That why parentral iron therapy is better option to treat such patients. ${ }^{9}$

Parenteral administration by intra-muscular injection is a painful alternative with a variable degree of efficacy. Alternative treatment methods for anemia include intravenous (IV) iron therapy or blood transfusion. Hematologic changes, like $\mathrm{Hb}$ and ferritin, are fairly rapid with IV iron therapy and have a positive effect on the body's iron storage which is measured by the Heamogram and different types of blood indices. ${ }^{10}$

Objectives of the study were comparing the efficacy of intravenous iron supplementation with iron sucrose to the oral supplementation with ferrous ascorbate in management of patient with post-partum anemia. Study the safety and side effects of these two preparations.

\section{METHODS}

This was a prospective study conducted on 100 postpartum anemic women in KG Hospital in Coimbatore, October 2012 to November 2013 with hemoglobin less than $10 \mathrm{~g} / \mathrm{dl}$ but more than $6 \mathrm{~g} / \mathrm{dl}$ within $24-48$ hours of delivery, after satisfying inclusion and exclusion criteria were included in the study. Sample size selected according to Mahajan's Formula.

\section{Inclusion criteria}

- $\quad$ Post-partum patient within 24-48 hours

- Post caesarean patient within 24-48 hours

- Women aged 18 years or more with

a) Hemoglobin less than $10 \mathrm{~g} / \mathrm{dl}$ but more than $6 \mathrm{~g} / \mathrm{dl}$

b) MCV: less than 80 femtoliter $\mathrm{MCH}$ : less than 27 picograms/cell MCHC: less than 32 grams/deciliter.

c) Blood picture-hypochromic, microcytic anemia or normochromic microcytic anemia.

\section{Exclusion criteria}

- Patient with anemia other than iron deficiency anemia

- $\quad$ Patient with H/o asthma, thromboembolism, seizures.

The patient with signs of infection or evidence of renal and hepatic dysfunction.

Patients were assigned to two groups randomly, each of 50. Their baseline hematological parameters like $\mathrm{Hb}$, HCT, Reticulocyte count, MCV, MCH, MCHC, Peripheral smear, were studied in Post-partum patients, 24 hours after delivery.

Group A - 50 registered pregnant women, who gave consent for intravenous iron sucrose therapy as per.

Table 1: Protocol of Iron sucrose dose.

\begin{tabular}{|lll|}
\hline Sr no. & Haemoglobin & Iron sucrose dose \\
\hline 1 & $8.6-9.5$ & $400 \mathrm{mg}$ \\
\hline 2 & $6-8.5$ & $800 \mathrm{mg}$ \\
\hline
\end{tabular}

Additional $50 \%$ of total dose given for restoration of iron stores.

All the doses given on IPD basis in the form of slow IV infusions

Group B - 50 delivered women B received three tablet of ferrous ascorbate containing $100 \mathrm{mg}$ of elemental iron and $5 \mathrm{mg}$ folic acid per day.

All baseline hematological parameters reassessed at end of 4 week. 
Data collection technique and tools: simple random sampling.

Hematological parameters like $\mathrm{Hb}$, HCT, reticulocyte count, MCV, MCH, MCHC, and peripheral smear, were assessed.

\section{Statistical analysis}

Data analysis was done using SPSS 20.0. Frequency distribution, mean, standard deviation and $\mathrm{p}$ value obtained by Pearson chi-square test were used for data analysis.

\section{RESULTS}

In both study groups majority of patients belonged to the age group of 17 to 24 years.

In study, mean hemoglobin of oral group was $8.49 \pm 0.75$ and mean hemoglobin of IV group was $8.43 \pm 0.76 ; 24$ hours after delivery. After treatment, that is after 4 weeks mean hemoglobin of oral group was $10.38 \pm 0.79$ and mean hemoglobin of IV group was $11.20 \pm 0.71$. On comparing both groups, the increase in hemoglobin in the IV groups was significant (Table 2).

Table 2: Comparison of mean haemoglobin between oral and IV group.

\begin{tabular}{|lll|}
\hline Mean haemoglobin & $\begin{array}{l}\text { After } 24 \\
\text { hours of } \\
\text { delivery }\end{array}$ & $\begin{array}{l}\text { After } 4 \\
\text { weeks of } \\
\text { delivery }\end{array}$ \\
\hline Oral group & $8.49 \pm 0.75$ & $10.38 \pm 0.79$ \\
\hline Paired samples t test & 17.287 & \\
\hline p value & 0.000 & $11.20 \pm 0.71$ \\
\hline IV group & $8.43 \pm 0.76$ & \\
\hline Paired samples t test & 22.849 & \\
\hline p value & 0.001 & \\
\hline
\end{tabular}

In study, an increase in mean HCT was observed from $25.74 \pm 3.13$ to $30.06 \pm 2.58$ in oral group. In IV groups an increase in mean HCT was noted from $25.74 \pm 2.45$ to $32.23 \pm 2.09$ at the end of 4 weeks. The increase in the HCT in the IV group was more significant (Table 3 ).

Table 3: Comparison of mean haematocrit between oral and IV group (PCV).

\begin{tabular}{|lll|}
\hline Mean hematocript & $\begin{array}{l}\text { After 24 } \\
\text { hours of } \\
\text { delivery }\end{array}$ & $\begin{array}{l}\text { After } 4 \\
\text { weeks of } \\
\text { delivery }\end{array}$ \\
\hline Oral group & $25.74 \pm 3.13$ & $30.06 \pm 2.58$ \\
\hline Paired samples t test & 8.654 & \\
\hline p value & 0.000 & \\
\hline IV group & $25.74 \pm 2.45$ & $32.23 \pm 2.09$ \\
\hline Paired samples t test & 14.399 & \\
\hline p value & 0.000 & \\
\hline
\end{tabular}

In study, mean MCV levels for the oral group was $72.72 \pm 9.93$, similarly it was for the IV group $74.59 \pm 5.72$ on the day $2^{\text {nd }}$. At the end of 4 weeks an increase in the mean MCV was observed from $74.59 \pm 5.72$ in oral group and $86.08 \pm 9.15$ in IV group respectively, which was statistically highly significant (Table 4).

Table 4: Comparison of mean MCV between oral and IV group.

\begin{tabular}{|lll|}
\hline MCV & $\begin{array}{l}\text { After 24 } \\
\text { hours of } \\
\text { delivery }\end{array}$ & $\begin{array}{l}\text { After 4 } \\
\text { weeks of } \\
\text { delivery }\end{array}$ \\
\hline Oral group & $72.72 \pm 9.93$ & $74.59 \pm 5.72$ \\
\hline Paired samples t test & 10.486 & \\
\hline p value & 0.000 & \\
\hline IV group & $73.81 \pm 11.49$ & $86.08 \pm 9.15$ \\
\hline Paired samples t test & 8.082 & \\
\hline p value & 0.000 & \\
\hline
\end{tabular}

In the present study, an increase in mean $\mathrm{MCH}$ was observed from $23.85 \pm 3.00$ to $25.19 \pm 1.91$ in oral group. In IV groups an increase in mean $\mathrm{MCH}$ was noted from $24.56 \pm 3.85$ to $32.75 \pm 9.80$ at the end of 4 weeks (Table 5).

Table 5: Comparison of mean $\mathrm{MCH}$ between oral and IV group discussion.

\begin{tabular}{|lll|}
\hline MCHC & $\begin{array}{l}\text { After 24 } \\
\text { hours of } \\
\text { delivery }\end{array}$ & $\begin{array}{l}\text { After 4 } \\
\text { weeks of } \\
\text { delivery }\end{array}$ \\
\hline Oral group & $30.13 \pm 2.38$ & $33.14 \pm 3.40$ \\
\hline Paired samples t test & 6.067 & \\
\hline P value & 0.000 & \\
\hline IV group & $29.33 \pm 3.59$ & $34.68 \pm 2.36$ \\
\hline Paired samples t test & 8.759 & \\
\hline P value & 0.000 & \\
\hline
\end{tabular}

In the present study the mean baseline MCHC was $30.13 \pm 2.38$ in oral groups and $29.33 \pm 3.59$ in IV groups respectively. At the end of 4 weeks treatment MCHC in the oral group $33.14 \pm 2.83$ and IV group $34.68 \pm 2.36$ which was statistically highly significant for the rise in MCHC in IV groups compared with the Oral group at the end of 4 week treatment (Table 6).

In the study the mean baseline reticulocyte count was $0.80 \pm 0.18$ in oral groups and $0.77 \pm 0.12$ in IV groups respectively. At the end of 4 weeks treatment reticulocyte count in the oral group $1.52 \pm 0.42$ and IV group $2.07 \pm 0.72$ which was statistically highly significant (Table 7).

Adverse effect noted in the oral group was $58 \%$ and in the IV group was $2 \%$ of the patient. GI side effects 
predominantly in the oral groups, may be affect the compliance of the patient.

Table 6: Comparison of mean MCHC between oral and IV group.

\begin{tabular}{|lll|}
\hline MCHC & $\begin{array}{l}\text { After 24 } \\
\text { hours of } \\
\text { delivery }\end{array}$ & $\begin{array}{l}\text { After } 4 \\
\text { weeks of } \\
\text { delivery }\end{array}$ \\
\hline Oral group & $30.13 \pm 2.38$ & $33.14 \pm 3.40$ \\
\hline Paired samples t-test & 6.067 & \\
\hline p value & 0.000 & \\
\hline Iv group & $29.33 \pm 3.59$ & $34.68 \pm 2.36$ \\
\hline Paired samples t test & 8.759 & \\
\hline p value & 0.000 & \\
\hline
\end{tabular}

Table 7: Comparison of mean reticulocytosis between oral and IV group.

\begin{tabular}{|lll|}
\hline Mean reticulocyte & $\begin{array}{l}\text { After 24 } \\
\text { hours of } \\
\text { delivery }\end{array}$ & $\begin{array}{l}\text { After } 4 \\
\text { weeks of } \\
\text { delivery }\end{array}$ \\
\hline Oral group & $0.80 \pm 0.18$ & $1.52 \pm 0.43$ \\
\hline Paired samples t test & 10.822 & \\
\hline p value & 0.000 & $2.07 \pm 0.72$ \\
\hline IV group & $0.77 \pm 0.12$ & \\
\hline Paired samples t test & 12.796 & \\
\hline p value & 0.000 & \\
\hline
\end{tabular}

\section{DISCUSSION}

In the present study, mean hemoglobin of oral group was $8.49 \pm 0.75$ and mean hemoglobin of IV group was $8.43 \pm 0.76 ; 24$ hours after delivery. After treatment, that is after 4 weeks mean hemoglobin of oral group was $10.38 \pm 0.79$ and Mean hemoglobin of IV group was $11.20 \pm 0.71$. On comparing both groups, the increase in hemoglobin in the IV groups was significant.

Similarly, mean reticulocyte count of oral group was $0.80 \pm 0.18$ and mean reticulocyte count of IV groups was $0.77 \pm 0.12,24$ hours after delivery. After treatment for 4 weeks, the mean reticulocyte count of oral group was $1.52 \pm 0.43$ and mean reticulocyte of IV group was $2.07 \pm 0.72$.

In a study by Bayoumeu $\mathrm{F}$ et al, in 50 pregnant patients with $\mathrm{Hb}$ levels between 8 and $10 \mathrm{~g} / \mathrm{dl}$ and a ferritin value of $<50 \mathrm{ug} / \mathrm{L}$. Treatment efficacy was assessed by measurement of hemoglobin and reticulocytes on days 8 , 15,21 and 30 and at delivery and of ferritin at delivery and on day 30. An increase in hemoglobin was observed, rising from $9.6 \pm 0.79 \mathrm{~g} / \mathrm{dl}$ to $11.11 \pm 1.3 \mathrm{~g} / \mathrm{dl}$ on day 30 in the intravenous iron sucrose group and from $9.7 \pm 0.5 \mathrm{~g} / \mathrm{dl}$ to $11 \pm 1.25 \mathrm{~g} / \mathrm{dl}$ on day 30 in the oral group. On day 30 and at delivery ferritin was higher in the iron sucrose group. It was concluded that iron sucrose appears to be a treatment without serious side effects indicated in correction of anemia in pregnancy or iron store depletion. $^{11}$

My study is comparable to the above study with respect to increase in hemoglobin.

\section{$M C V$}

In present study, mean MCV levels for the oral group was $72.72 \pm 9.93$, similarly it was $74.59 \pm 5.72$ for the IV group on the day $2^{\text {nd }}$. At the end of 4 weeks an increase in the mean MCV was observed from $74.59 \pm 5.72$ in oral group and $86.08 \pm 9.15$ in IV group respectively. On comparing both groups, the increase in MCV in IV group was significantly better at the end of 4 weeks ( $p$ value0.000).

In a randomized study conducted by Swati A and et al, the $\mathrm{MCV}$ was $72.16 \pm 12.01 \%$ in oral group and $73.90 \pm 6.86 \%$ in IV group. After treatment MCV count in oral group was $82.09 \pm 7.71 \%$ and $82.50 \pm 6.99 \%$ in IV group. The increase of MCV was significant in the IV iron group compared to oral iron group. Hence both studies were comparable. Although my study and the above mentioned study show significant increase in IV groups. the increase was much more probably due to increased dose of the iron sucrose. The increase in MCV in oral group in my study is less comparable to that of Swati A oral group, probably due to less compliance to the oral iron in my groups. ${ }^{12}$

\section{$\mathrm{MCH}$}

In the present study, an increase in mean $\mathrm{MCH}$ was observed from $23.85 \pm 3.00$ to $25.19 \pm 1.91$ in oral group. In IV groups an increase in mean $\mathrm{MCH}$ was noted from $24.56 \pm 3.85$ to $32.75 \pm 9.80$ at the end of 4 weeks. On comparing both groups, the increase in MCV in IV group was significantly better at the end of 4 weeks. Study was statistically highly significant $(p-0.00)$ for the rise in mean $\mathrm{MCH}$ in IV groups compared to the oral groups at the end of 4 weeks treatment.

In a randomized study conducted by Swati A and et al, $\mathrm{MCH}$ was $24.34 \pm 5.16 \%$ in oral group and $25.57 \pm 4.43 \%$ in IV group. After treatment $\mathrm{MCH}$ count in oral group was $32.72 \pm 4.34 \%$ and $33.48 \pm 4.35 \%$ in IV group. ${ }^{12}$ The increase of $\mathrm{MCH}$ was significant in the IV iron group compared to oral iron group. Hence both groups were comparable. Hence both studies were comparable. Although my study and previous above study show significant increase in IV groups. The increase was much more probably due to increased dose of the iron sucrose. The increase in $\mathrm{MCH}$ in oral group is less comparable to that of Swati A probably due to less compliance to the oral iron in my groups. ${ }^{12}$

In the present study the mean baseline MCHC was $30.13 \pm 2.38$ in oral groups and $29.33 \pm 3.59$ in IV groups respectively. At the end of 4 weeks treatment MCHC in 
the oral group $33.14 \pm 2.83$ and IV group $34.68 \pm 2.36$ which was statistically highly significant ( $\mathrm{P}$ value- 0.000$)$ for the rise in MCHC in IV groups compared with the oral group at the end of 4 week treatment.

In Swati A randomized study the MCHC was $32.22 \pm 4.03 \%$ in oral group and $31.75 \pm 4.56 \%$ in IV group. After treatment MCHC count in oral group was $37.79 \pm 4.94 \%$ and $37.17 \pm 4.224 \%$ in IV group. The increase of MCHC was significant in the IV iron group compared to oral iron group. ${ }^{12}$

\section{CONCLUSION}

Our study illustrate clearly that intravenous iron sucrose complex is safe, convenient and effective in postpartum anemic women as compared with the oral ferrous ascorbate statistically significant increase in value of haemoglobin, hematocript, reticulocyte count, R.B.C. indices (MCH, MCV, MCHC) with no serious side effect.

Intravenous iron sucrose have shorter treatment periods, increased likelihood of compliance, a lack of gastrointestinal side effects, and rapid replenishment of iron stores, making them superior to oral ferrous ascorbate. The only disadvantage of intravenous treatment is cost and invasive nature of the procedure, but it ensures supervised iron treatment and unquestionable compliance.

Intravenous iron sucrose can be used as safe and effective alternative to blood transfusion and oral iron therapy in the treatment of iron deficiency anemia in the postpartum period.

The hospital stay of postpartum women thus can be effectively utilized by giving a fixed dose of intravenous iron sucrose.

\section{ACKNOWLEDGMENTS}

Authors would like to thank to Dr. G. Bakthavathsalam, M. S., Chairman and Head of the Institution, K. G. Hospital, Coimbatore, Dr. N. Satyavathy and Dr. Kumudhini for permitting and supporting me to conduct this study.

Funding: No funding sources Conflict of interest: None declared

Ethical approval: The study was approved by the Institutional Ethics Committee

\section{REFERENCES}

1. Beard JL, Hendricks MK, Perez EM. Maternal iron deficiency anemia affects postpartum emotions and cognition. J Nutr. 2005;135:267-72.

2. Perez EM, Hendricks MK, Beard JL. Mother-infant interactions and infant development are altered by maternal iron deficiency anemia. J Nutr. 2005; 135:850-5.

3. Rienold C, Dalenius K, Smith B, Brindley P, Grummer-Strawn L. Pregnancy nutrition surveillance 2007 report. Atlanta: U.S. Department of Health and Human Services, Center for Disease Control and Prevention; 2009.

4. Bodnar L, Scanlon K, Freedman D. High prevalence of postpartum anaemia among low income women in the United States. J Obstet Gynecol. 2001;185:434853.

5. Beard JL, Hendricks MK, Perez EM. Maternal iron deficiency anemia affects postpartum emotions and cognition. J Nutr. 2005;135:267-72.

6. Henly, Anderson, Avery, Hills-Bonczyk, Potter, Duckett, Anemia and Insufficient Milk in First-Time Mothers. Birth. 1995;22(2):86-92.

7. Bhandal N, Russell R. Intravenous versus oral iron therapy for postpartum anemia. BJOG. 2006; doi:10. 1111/j.1471-0528. 2006.01062.

8. Firkin F, Perington D, Rush B. DeGruchy's clinical hematology in clinical practice. Hypochromic anemias: Iron deficiency and Sideroblastic. eds., Publication. Fifth edition. 1989:31-60.

9. Silverstein SB, Rodgers G. Parenteral iron therapy options. Am J Hematol. 2004;76:74-8.

10. Hallak M, Sharon AS, Diukman R, Auslender R, Abramovici. Supplementing iron intravenously in pregnancy. A way to avoid blood transfusions. J Reprod Med. 1997;42(2):99-103.

11. Breymann C. Treatment of iron deficiency anaemia in pregnancy and postpartum with special focus on intravenous iron sucrose complex. J Med Assoc Thai. 2005;88 Suppl 2:S108-9.

12. Agarwal S, Gupta M, Juneja M, Jain S. Evaluation of iron sucrose for post partum anemia. Int J Basic Applied Med Sci. 2013;3(2):208-11.

Cite this article as: Mhaske G, Vadehra P, Maran C. Compare the safety and efficacy of intravenous iron supplementation with iron sucrose to the oral supplementation with ferrous ascorbate in subjects with post-partum anemia. Int J Reprod Contracept Obstet Gynecol 2019;8:3590-4. 